\title{
The Role of the Spiritist Community Brotherhood in Radvance, Silesia in the Organization of the Czechoslovak Spiritist Movement
}

Andrea Hudáková / e-mail: andre.hudakova@htf.cuni.cz

Protestant Theologian Faculty Charles University in Prague, Czech Republic

Hudáková, R. (2013). The Role of the Spiritist Community Brotherhood in Radvance, Silesia in the Organization of the Czechoslovak Spiritist Movement. Czech-Polish Historical and Pedagogical Journal, 5/2, 70-72.

doi: 10.2478/cphpj-2013-0015

Members of the Czechoslovak spiritist movement were trying to form a unified national organization continuously from the beginning of the $20^{\text {th }}$ century, however, they only managed to found several regional centres. In Silesia it was the Spiritist Community Brotherhood which coordinated the process of unification of spiritists in Silesia, Moravia and Slovakia. Spiritist movement in the area was also influenced by Life, another community in Moravská Ostrava.

Key words: spiritist movement; Silesian spiritists; Spiritist Community Brotherhood

The first major meeting of Czech spiritists took place in Prague in 1895. ${ }^{1}$ The primary objective was to discuss the future form of the spiritist organization in the Lands of the Bohemian Crown. Silesian spiritists participated in these discussion from 1903.2 The main issue was to resolve, whether spiritists should organize themselves though an oficial society, or whether they should cooperate unoficially. Austro-Hungarian authorities repeatedly took actions against Czech spiritists, therefore spiritist communities did not state the word "spiritism" in their names or in their statutes.

At the meeting of Silesian spiritists in Stonava in March 1914 it was decided to take necessary steps and build a spiritist house ${ }^{3}$ with a lecture hall and a community room. The house was built the same year in Radvanice by the newly formed Construction Community Brotherhood [Stavební spolek Bratrství]. 4 The community was renamed for Spiritist Community Brotherhood [Spiritistický spolek Bratrství] on the basis on new statutes approved in 1920 after Czechoslovakia was founded.

Former community statutes from 1914 did not contain any specific rules for the members, nevertheless, they adjusted in detail conditions

\footnotetext{
Historie spiritismu a jeho vývoj (1903), Hrabačov, p. 43.

Posel záhrobní, 9/1903 (3), p. 142.

Rösner, J. (1927): Spiritismus ve Slezsku. Radvanice, p. 41.

Zemský archiv v Opavě [Provincial Archives in Opava], (ZAO), f. Policejní ředitelství Moravská Ostrava 1854-1945 (PŘ MO), b. 1071/957.
} 
under which the community houses were to function. These conditions banned serving and drinking alcoholic beverages, smoking, playing immoral games, gambling, breeding and slaughtering animals and consuming meat. ${ }^{5}$ At the same time, these restrictions also precisely expressed spiritual requirements on members of the community. At a meeting of a group of Silesian spiritists in 1907, even before establishing the Construction Community Brotherhood they accepted a resolution which claimed that whoever intends to be a true spiritist needs to be an abstinent, non-smoker, vegetarian, cannot gamble and fornicate, cannot be a member of any religious sect and has to live morally and virtuously. ${ }^{6}$ Although these rules were not acceptable for all the spiritist groups in Silesia, they became the very basis of the Spiritist Community Brotherhood official activities.

Therefore, only an abstinent, non-smoker, vegetarian and a nonconfessional person could become a regular member of the community. ${ }^{7}$ The strict statutes were also accepted by Czechoslovakian spiritists in Vienna, ${ }^{8}$ spiritist community in Locenice $^{9}$ in southern Bohemia and Educational Community Jiskra [Vzdelávajúci spolok Jiskra] in Bratislava, ${ }^{10}$ which coordinated spiritist in western and central Slovakia.

Jan Kuchař and Jan Rösner were the two leading personalities of the Spiritist Community Brotherhood from the creation of the community until 30 years later. The community had its drama company, orchestra and two choirs. It organized concerts, theatrical plays, exhibitions of media paintings and public lectures, especially from the field of occult science and healthy lifestyle popularization. The community unified spiritists in Silesia in 11 so-called county centres. These were to be found for example in Bohumín, Těšín, Karviná, Petřvald and Frýdek.

In 1927 they had already 400 members and the spiritist house's capacity was not sufficient anymore. ${ }^{11}$ In 1931 the community, supported by donations built and ceremonially opened a new hall at the occasion of a national meeting of spiritists which took place in Radvanice. The hall was designed to be a theatre with 500 seats. In 1921, a community called Brotherhood also constructed an edifice for the newly founded

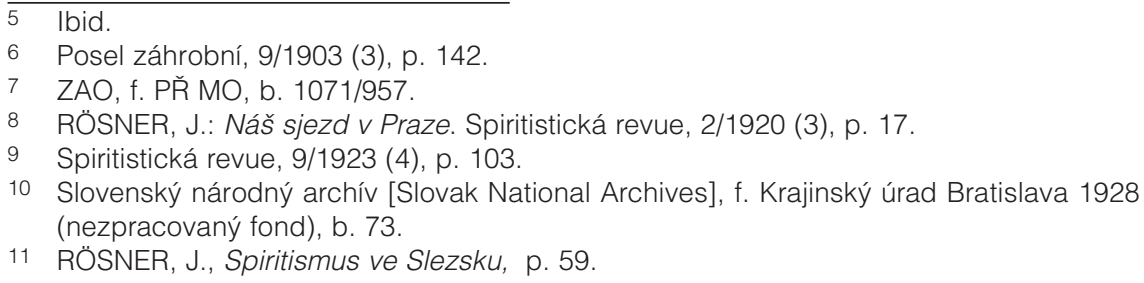


Spiritistická revue that was edited by Jan Rösner until 1947. This revue became the main communication tool of the organized spiritist movement directed from Radvanice.

Along with the Spiritist Community Brotherhood, it was Život in Moravská Ostrava, a community founded in 1922 by Ferdinand Kučera, ${ }^{12}$ former vice-chairman of the Construction Community Brotherhood, which unified spiritists in Silesia. Kučera also published and edited a community revue Život, which was being published from 1924 until 1928. The community had its centres in Louky ${ }^{13}$ (today's Karviná), Karviná, ${ }^{14}$ Hranice and Uherský Ostroh 15 in southern Moravia. In 1925 there were 223 members. ${ }^{16}$ During the same period the community also built its twostoreyed house with a hall, community rooms and apartments in Mariánské Hory. ${ }^{17}$ In 1930's the community Život started to cooperate within the organized spiritist movement in Czechoslovakia, however, the number of their own members considerably decreased, as a consequence of repeated changes of its leaders.

After the Second World War, many spiritist communities in Czechoslovakia renewed their activities. Among others, there was a Spiritist Community Brotherhood in Radvanice, which continued in its prewar role and endeavoured to unify Czechoslovakian spiritists again. In 1947 the community counted more than 160 members $^{18}$ and regular activities including public lectures were held until the spring of 1951. In July 1951, its activities were officially stopped and the community house was confiscated. ${ }^{19}$ Similary, all the Czechoslovakian spiritist communities were officially prevented from continuing their activities in 1948, as the political regime transformed.

\footnotetext{
12 ZAO, f. PŘ MO, b. 2165/848.

13 Život, 1/1925 (4), pp. 13.

14 ZAO, f. PŘ MO, b. 2165/848.

15 ZAO, f. PК̆ MO, b. 1191.

16 Ibid.

17 Život, 12/1924 (3), pp. 143-144.

18 ZAO, f. PŘ MO, b. 1071/957.

19 Ibid.
} 